\title{
Upflow Solid Contact Clarifier
}

(Terbit di Majalah Air Minum, Januari 2017)

Oleh Gede H. Cahyana

Pada edisi kali ini Sainstek akan menampilkan sebuah unit pengolahan air minum yang sederhana tetapi tepat guna dengan sumber air dari mata air atau dari sungai yang relatif rendah kekeruhannya. Unit ini menggabungkan unit proses dan operasi koagulasi, flokulasi, separasi zat padat dan sludge removal. Ada juga yang menyebutnya dengan filter. Tidak salah memang, tetapi kurang tepat karena unit ini terdiri atas beberapa unit operasi dan proses. Unit ini tidak membutuhkan flokulator dan sedimentasi secara terpisah. Di Amerika Latin disebut upflow solid contact clarifier. Dalam bahasa yang lebih praktis bisa disebut Floklater: flokulator, klarifir, filter.

Berdasarkan hasil penelitian pada unit skala pilot dan penuh, unit Floklater cocok diterapkan untuk air baku dengan kekeruhan hingga 50 JTU atau $150 \mathrm{mg} / 1$ suspended solid. Di Indonesia barangkali belum ada PDAM yang menerapkan unit jenis ini. Sejenis unit upflow slow sand filter (USSF) sudah ada, dibuat oleh BPPT tetapi untuk skala perumahan kecil. Bedanya, unit Floklater sudah termasuk USSF, klarifikasi, flokulasi, (dan flash mixing). Contoh diagramnya diberikan pada Gambar 1. Laju filtrasi atau beban permukaan yang bisa diterapkan antara $120-150 \mathrm{~m} 3 / \mathrm{hari} / \mathrm{m} 2$.

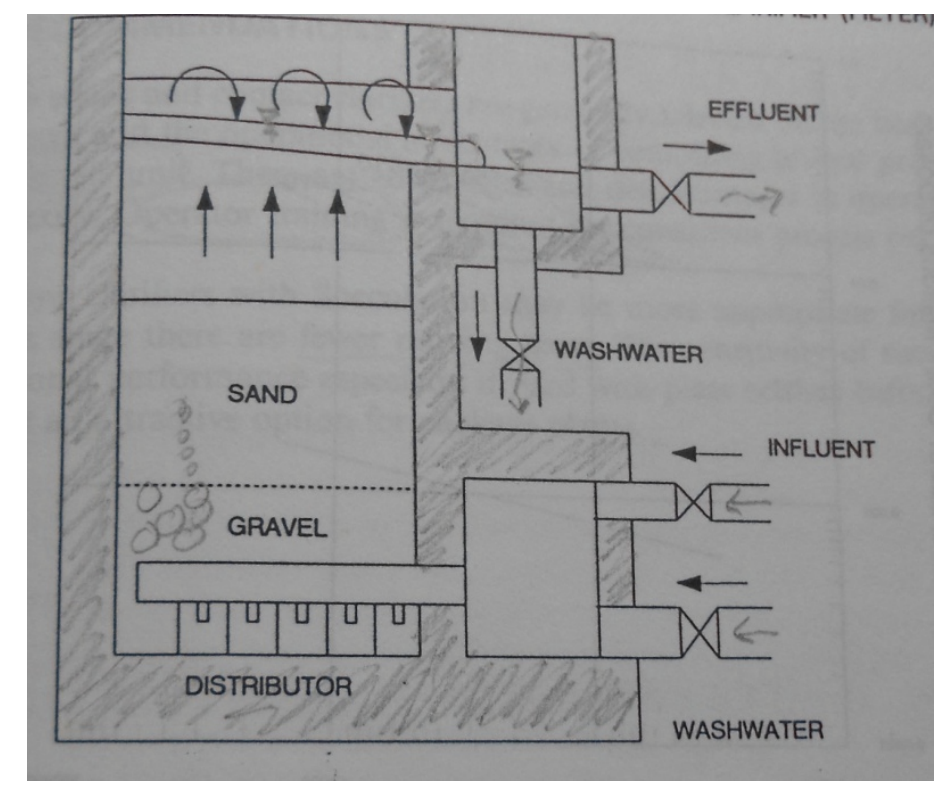


Adapun hubungan antara biaya konstruksi terhadap luas efektif diberikan pada Gambar 2. Pada gambar ini diketahui bahwa dengan luas efektif 10.000 square feet diperoleh biaya konstruksinya kurang lebi 0,8 juta dollar atau sekitar 11,2 miliar rupiah (tahun 2016, asumsi 1 USD $=$ Rp14.000). Faktor konversi 1 sq.ft $=0,09 \mathrm{~m} 2$, sehingga 10.000 sq.ft $=900 \mathrm{~m} 2$. Dengan bentuk alas bak persegi maka panjang sisi bak $=30 \mathrm{~m}$. Luas ini mampu menghasilkan air olahan antara $108.000 \mathrm{~m} 3 /$ hari - $135.000 \mathrm{~m} 3 /$ hari.

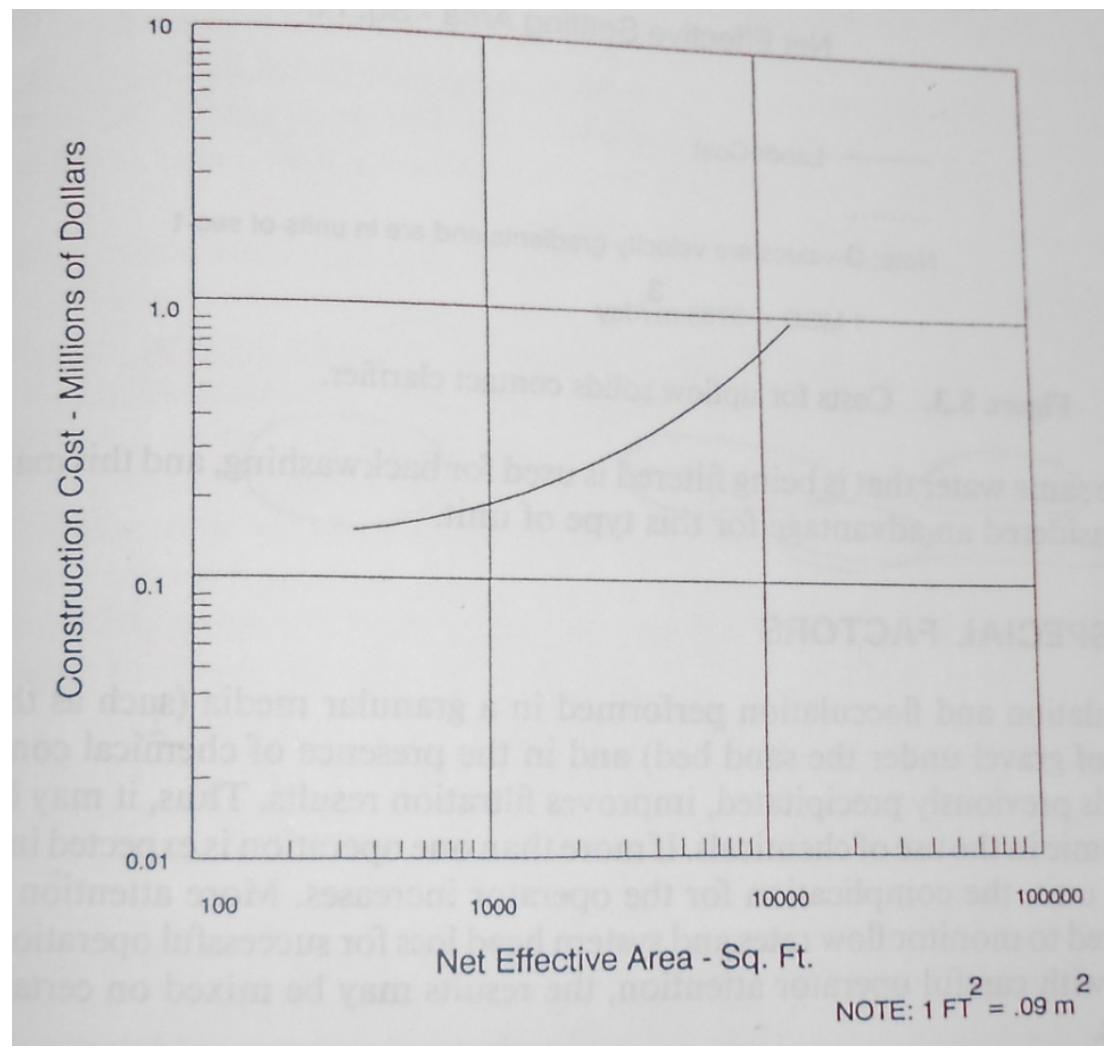

Untuk masyarakat perdesaan, asumsi kebutuhan air minum adalah 100 1/orang/hari. Maka total penduduk yang bisa dilayani air minum adalah 1.080 .000 orang hingga 1.350.000 orang. Maka diperoleh koefisien biaya proyek pada tahun pertama adalah Rp10.370/orang sampai dengan Rp8.296/orang. Relatif murah. Karena sederhana dan relatif murah, maka unit ini banyak digunakan di negara-negara berkembang di Amerika Latin dan mudah-mudahan saja bisa digunakan di perdesaan Indonesia.

Mekanisme separasi koloid, suspended solid, dan flok terjadi secara berurutan mulai dari zona kerikil, pasir dan ruang storasi di bawah sludge blanket. Hal inilah keutamaan Floklater yaitu mampu membentuk selimut padatan ringan di bagian atas dengan 
densitas seragam sehingga menghasilkan ruang di bagian bawahnya sebagai ruang storasi untuk menyisihkan padatan yang lebih besar (lebih berat). Untuk membantu media atas tidak hanyut (washout) ke bagian efluen maka bisa juga dipasang kawat kasa atau yang bentuknya seperti jarring di bagian atas unit, di bawah zone outlet.

Apabila dipandang perlu, maka proses bisa dilengkapi dengan koagulasi dan flokulasi yang terjadi di dalam media berbutir, yaitu media kerikil. Dengan adanya zat kimia berupa koagulan yang ditambahkan sebelumnya, maka hasil pengolahan menjadi lebih jernih. Dosis koagulan bisa dihemat karena mikroflok yang terbentuk tetap bisa disisihkan dari aliran air di media pasir. Namun demikian, karena terdiri atas banyak unit dalam satu paket pengolahan maka kompleksitas operasi dan perawatan pun bertambah. Floklater lebih rumit dibandingkan dengan unit proses dan operasi yang terpisah atau pengolahan konvensional.

Yang perlu dimonitor adalah laju aliran airnya dan head loss yang terjadi selama pengaliran air. Apabila kecepatan hidrolisnya terlalu besar maka material padatan halus akan lolos ke zone outlet di bagian atas unit. Ini harus dicegah. Tetapi positifnya, air baku yang sedang diolah ini justru bisa berfungsi sebagai air pencuci endapan flok di rongga media kerikil dan pasir. Agar diperoleh kualitas efluen yang lebih jernih lagi maka bisa ditempuh dengan pemasangan plate settler.

Lebih dari semua itu, kemampuan operator adalah hal terpenting. Agar pengolahannya berlangsung dengan baik dan betul, maka training operator diperlukan secara berkala agar mampu mengoperasikan unit Floklater secara berhasil guna dan berdaya guna. * 